\title{
頭蓋咽頭腫における石灰化巣形成過程の電子顕微鏡的観察
}

\author{
佐藤 一史 久保田紀彦・林実 山本信二郎*
}

\section{Fine Structural Study of the Mineralization Process in Craniopharyngioma}

\author{
Kazufumi Sato, Toshihiko Kubota, Minoru Hayashi and Shinjiro Yamamoto* \\ Department of Neurosurgery, Fukui Medical School, Fukui; *Department of Neurosurgery, University of \\ Kanazawa, Kanazawa
}

\begin{abstract}
The calcification process in eight cases of adamantinomatous craniopharyngioma was studied at the ultrastructural level. The neoplastic cells, which constituted the internal and intermediate zones of the tumor, frequently displayed abundant cytoplasmic tonofibrils and, occasionally, keratinization. In most of the degenerated keratinized cells, the intracytoplasmic organelles had disappeared. In these cells, membrane-bound vesicles measuring approximately 0.15 to $0.5 \mu \mathrm{m}$ in diameter, were frequently seen among the numerous tonofibrils. Needle-like, mineralized crystals were precipitated some vesicles. Tiny, calcified vesicles were sometimes aggregated and had coalesced with the adjacent tonofibrils to form a large, calcified mass.

These findings suggest that membrane-bound vesicles are derived from degenerated keratinized cells and play an important role as initial nidi of calcification in craniopharyngioma. Remnants of tonofibrils of degenerated cells may also serve as foci of mineralized crystal deposition.
\end{abstract}

Key words: craniopharyngioma, calcification, electron microscopy

\section{I はじめに}

頭蓋咽頭腫は，全頭蓋内腫瘍の $2.5 \sim 5.8 \% 20,22,23)$ を占め, 日本人に比較的多い脳腫瘍である，本腫瘍は石灰化を伴い， やすい脳腫瘍として知られているが，その石灰化巣の超微 細構造に関する記載は少ない, $10,12,17,18)$ 生体組織の石灰化 の機序に関して, Anderson ${ }^{1)}$ とBonucci洸は米国と伊国で 別々に，正常発育動物の関節軟骨の石灰化巣内に，超微細 構造上単位膜に包まれた直径 $0.03 \sim 1.0 \mu \mathrm{m}$ の類円形の小 体を初めて見い出し， matrix vesicle1) あるいは calcifying globules ${ }^{6)}$ と呼称した。 そして，この小体に針状結晶の沈 着物を観察し，この小体が石灰沈着の起こる最初の場であ るとした，この事実は，生理的病的石灰化の一般的な初 期像の一つとして現在広く認められている2,3) また，最
近では石灰化におけるミトコンドリアの機能が重視されて おり，実際にミトコンドリアに最初の石灰沈着が起こるこ とが報告されている3,11,15)

今回我々は，手術的に摘出され電顕的に石灰化を認め之 た頭蓋㸶頭腫の石灰化巣の観察を行った，前述の類円形の 石灰化小体は，本腫場の石灰化巣内にも観察しえた。これ らの小体の形態を主眼に, 本腫晹の石灰化宩の形成過程を 検討したので報告する。

\section{II 対象および方法}

頭蓋咽頭腫16例につき電顕的観察を行い,このらち石灰 化像を捉ええた 8 例を対象とした。

手術により摘出した材料をただらに $2.5 \%$ グルタールア ルデヒド固定液( $\mathrm{pH} 7.4$ の0.1 M カコジル酸緩衝液)で約 2

\footnotetext{
福井医科大学脳神経外科 *金沢大学船神経外科

Address reprint requests to: K. Sato, M.D., Department of Neurosurgery, Fukui Medical School, 23 Shimoaizuki, Matsuoka-cho, Yoshidagun, Fukui 910-11.

受稿 1986年9月8日受理 1987 年6月15日
} 
時間固定し， $1 \%$ オスミウム酸による後固定を約 2 時間行 った。上昇ェターール系列で脱水後, エポン812-アラルダ イト502混合樹脂で包埋した. 超薄切片はダイヤモンドナ イフで作製し，酢酸ウラーールとクェン酸鉛で染色し，日 立 H-600型透過電顕で観察した。 また， 2 例の超薄切片に おいて、エネルギー分散型微小 $\mathrm{X}$ 線分析装置 (Kevex)を 用い近接スペクトルの定性分析を行った。

\section{III 結 果}

\section{1. 光学顕微鏡的観察}

石灰化を認めた 8 例は，すべてェナイル上皮腫型の頭蓋 咽頭腫であった(Fig. 1)，腫瘍実質細胞は基底層，中間 層, および内層の 3 層構造を成し, 後 2 者の細胞層内には 角質細胞巣を認め, 腫瘍細胞は数個が集合し島状に散在し ていた。これらの細胞の胞体はエオジン好性で徽細線維状 であり，核は円形あるいは棈円形であるが，核が消失した 細胞も多く認められた. 角質細胞巣内の石灰化は 8 例全例 に認められ，HE染色で紫紅色に染まる顆粒状あるいは同 心円状構造を示した。 また，腫瘍の間質内および腫瘍周囲 のグリオージス内の石灰化を各 1 例に認めた.

\section{2. 電子顕微鏡的観察}

基底層を形成する細胞は一般に円柱形で，細胞内には径 5〜6 nm の微細線維(tonofilament)が集合して束状となり, $0.1 \mu \mathrm{m}$ 前後の線維束を形成していた(Fig. 2). 線維は細胞 の長軸にほぼ平行に，あるいは不規則に走行しており，一

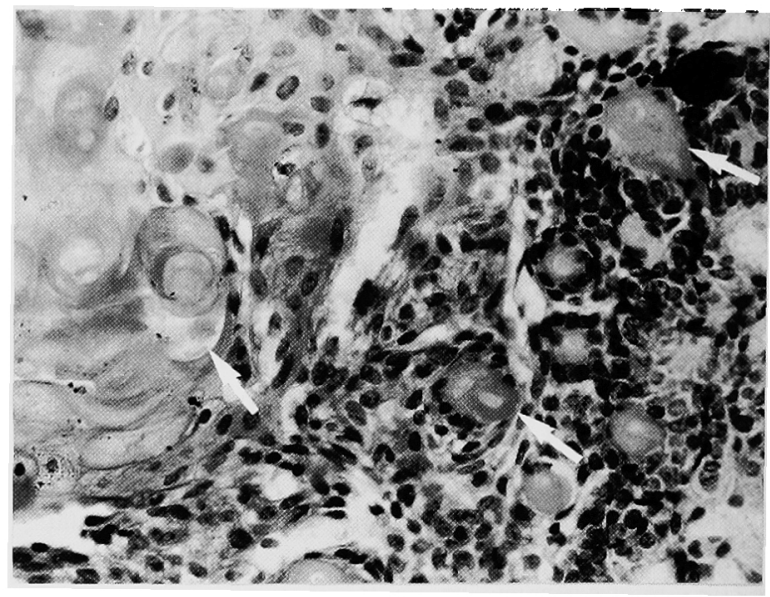

Fig. 1 Light photomicrograph of an adamantinomatous craniopharyngioma showing islands of keratinized cells associated with tiny calcified masses (arrow). HE stain, $\times 260$.

部の tonofilament は desmosome に結合し、いわゆる desmosome-tonofilament complex 形成していた，中間層 において tonofilament はその数を增し，互いに瘉合する傾 向を示した。内層の細胞は一般に胞体が小さく星芒状であ り，細胞間隙の拡大をみた，中間層および内層には胞体の 大きな角質細胞が散在していた。これらの細胞には核の残 存しているものと消失したものが存在した。核の残存して
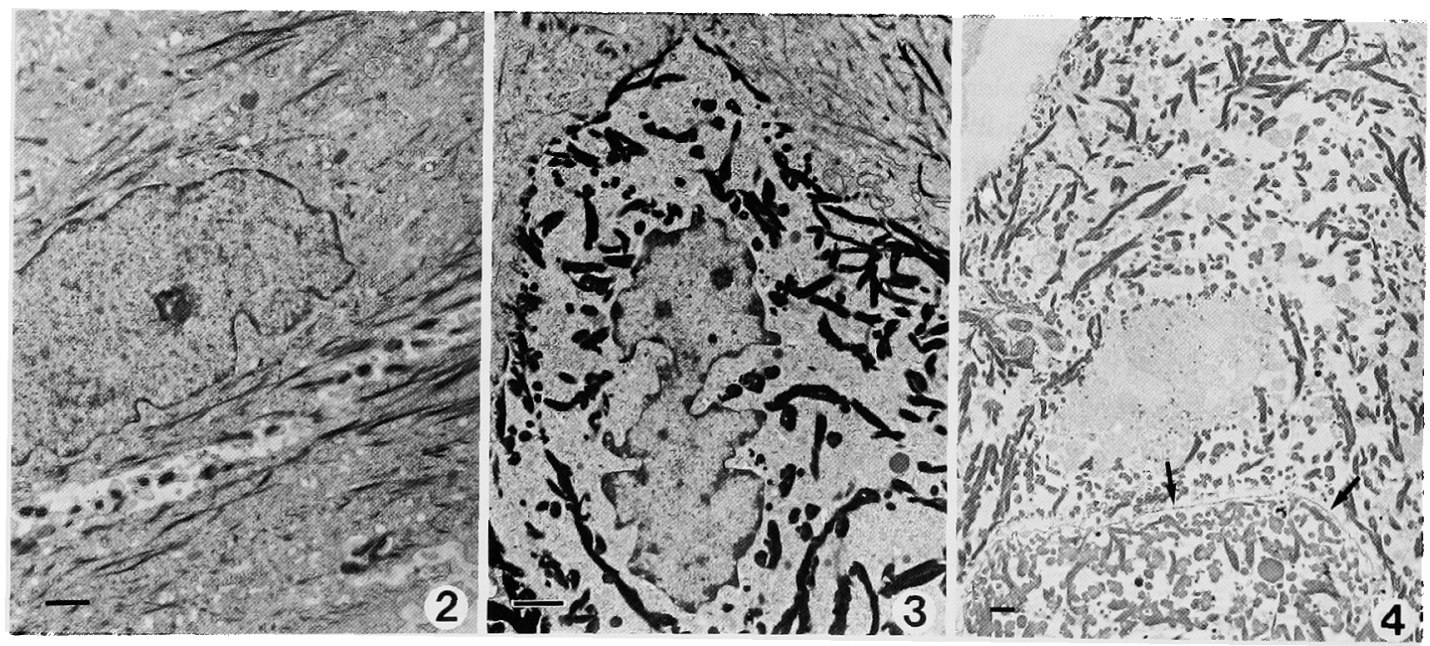

Fig. 2 Electron photomicrograph of the neoplastic cells in a basal zone of the tumor. Prominent tonofilaments, as well as numerous desmosomes, are present. Bar $=1 \mu \mathrm{m}$.

Fig. 3 Large numbers of stout tonofibrils are seen in a keratinized cell located in the intermediate zone. Bar=1 $\mu \mathrm{m}$.

Fig. 4 Degenerated keratinized cells exhibiting many remnants of tonofibrils and cellular debris. An interrupted unit membrane is observed as well (arrows). $B a r=1 \mu \mathrm{m}$. 
いる細胞では，核は切れ込みが多く不整形であり，胞体内 には平常 tonofilament が多数集簇し, 径 $0.2 \sim 0.7 \mu \mathrm{m}$ の電 子密度の高い線維束 (tonofibril) を形成していた(Fig. 3)。 Tonofibril はほぼ核を取り囲むよらに走行し，線維間には 遊離リボゾーム, 粗面小胞体, ミトコンドリア,ゴルジ装 置が広く分布していた。一方，核の消失した角質細胞の胞 体は，全体に明るいことが多かった(Fig. 4)。これらの細 胞の tonofibril の電子密度は，一般に低下していた．細胞 膜は消失していることが多いが，角質細胞が互いに隣接す る部分では不連続の単位膜を認めることがあった。これら の変性した角質細胞の tonofibril 間には, 細胞内小器官の 残屑に混じて直径 $0.15 \sim 0.5 \mu \mathrm{m}$ の多数の類円形小体の出 現を見た(Fig. 5A)。そして，一部の小体には長さ0.05〜 $0.15 \mu \mathrm{m}$ ，径約 $10 \mathrm{~nm}$ の針状結晶の集積が認められ，これ は小体の膜上あるいは内部に放射状 同心円状に蓄積して いた(Fig. 5B)。これらの石灰化小体に針状結晶が多数付 着した状態では，その膜構造は不明瞭であった。また，こ の石灰化巣の一部が tonofibril と癒着している部分も認め られた(Fig. 6)．石灰沈着の大きな部位では針状結晶は多 数の tonofibril 上に沈着し，その周囲にも石灰沈着を多数 認めた(Fig. 7). Tonofibril 間に針状結晶の集積が及ぶと, 1 個の細胞全体を埋め尽くすほどの大きな石灰化巣となり (Fig. 8)，その中心部にはいまだ針状結晶の付着を見ない tonofibril の一端を認めることがあった．

微小X線分析では，カルシウムと燐に大きなピークが 認められた(Fig. 9)。また，メッシュによる銅のピークも 認めた。
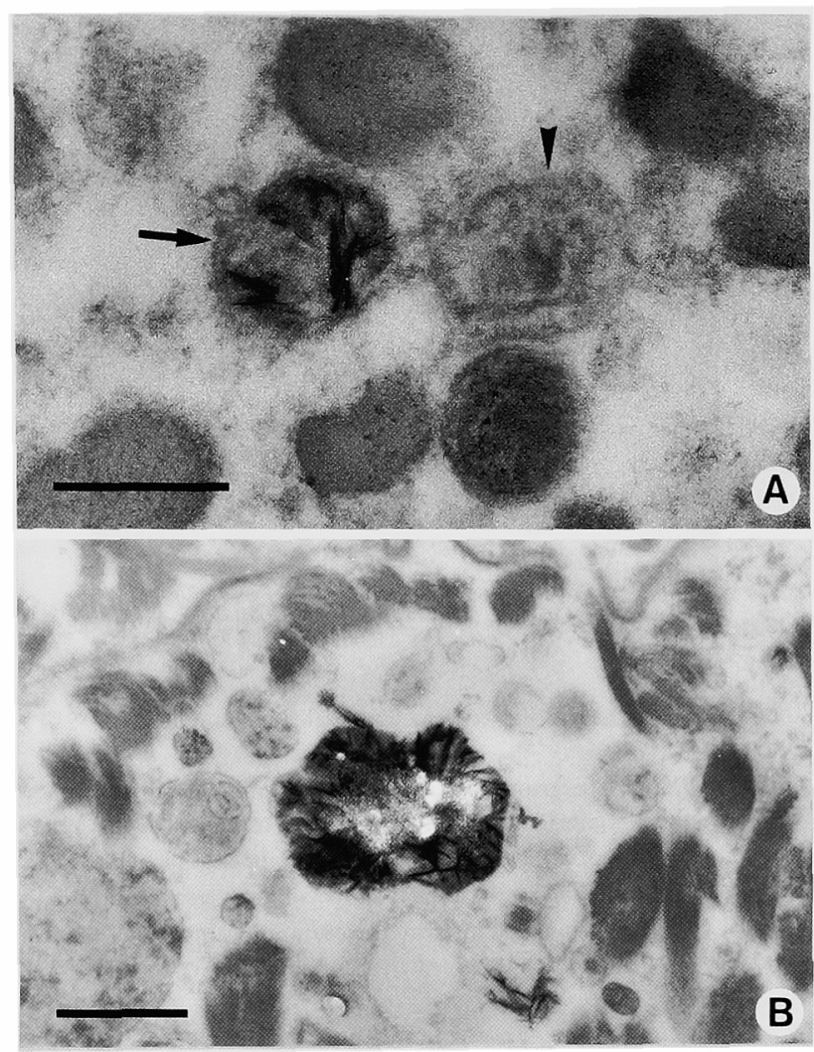

Fig. 5 A: Membrane-bound vesicles (arrowhead) in a degenerated keratinized cell. Some of the vesicles contain needle-shaped crystals (arrow). Bar $=0.25 \mu \mathrm{m}$. B: A vesicle showing radial accumulation of needle-shaped crystals. $B a r=0.25 \mu \mathrm{m}$.

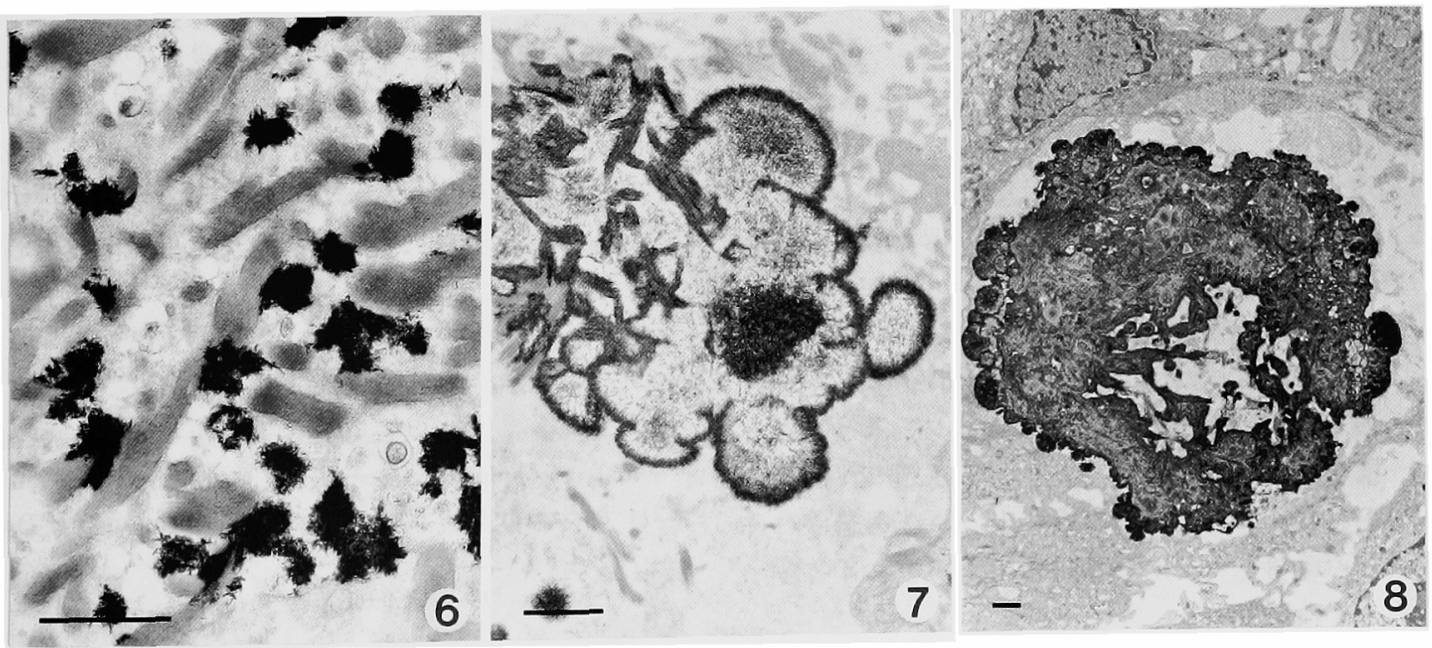

Fig. 6 Abundant calcified vesicles, some adherent to tonofibrils, are seen. $B a r=1 \mu \mathrm{m}$.

Fig. 7 A large, calcified conglomeration comprising numerous calcified tonofibrils. $B a r=1 \mu \mathrm{m}$.

Fig. 8 A huge, calcified mass consisting of coalesced fibrillar and vesicular calcified material. Bar=1 $\mu \mathrm{m}$. 


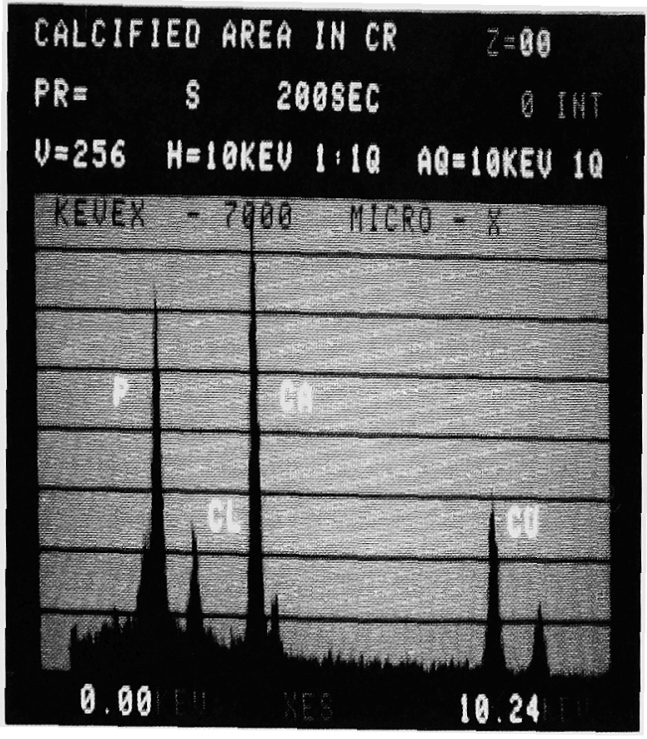

Fig. $9 \mathrm{X}$-ray spectrum obtained from a sample of the mineralized material, showing peaks for calcium (CA) and phosphorus (P). The copper (CU) peak reflects the activity of the underlying copper support grid. Chloride (CL) may originate from the craniopharyngioma tissue.

\section{$\mathbf{N}$ 考察}

頭蓋咽頭腫の角質細胞巣内に石灰化が生じることは, 光 顕上古〈から知られている8 ${ }^{8}$ 今回の検索においても，腫 瘍実質の上皮細胞層内の石灰化の汪とんどは角質細胞巣内 に認められた，本腫瘍の石灰化の超微細構造に関する今ま での記載のらち, Ghatak ら ${ }^{10)}$ は keratinすなわち tonofibril

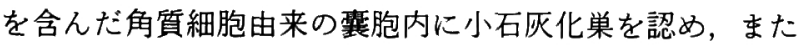
この襄胞に隣接した大きな石灰沈着を観察した．高倍率の 観察では，この大石灰化巣は針状結晶の集合であるとして いる，Landolt ${ }^{18)}$ は，本腫瘍にみられる角化を皮膚に打け る生理的な角化像7) と対比し, 異常角化の一形態であると している.そして, homogeneous bundle (tonofibril) 間に は細胞の残骸のみが存在したとし，その一部に tonofibril に付着した針状結晶の集塊を認めた，我々は初めて，超徽 細構造上变性に陥った角質細胞の tonofibril の間に単位膜 に包まれた直径 $0.15 \sim 0.5 \mu \mathrm{m}$ の類円形の小体を観察した. そして，一部の小体にはその膜上あるいは内部に針状結晶 の沈着がみられた，これが超微細構造上，頭蓋咽頭腫の石 灰化巣形成におけるもっとも初期の形態であると考えられ る.

今回, 頭蓋咽頭腫に認められた石灰化小体の本態につい

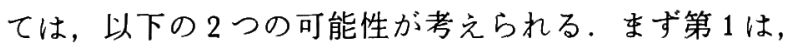
matrix vesicleである. Matrix vesicle は軟骨1,6)。骨5)。歯
芽4,9)などの生理的石灰化組織のみならず, aortic valve ${ }^{13)}$, meningioma ${ }^{14,16)}$. osteogenic sarcoma ${ }^{19)}$ などに生じる病的 石灰化巣にもその存在が指摘されている.この matrix vesicle の成因に関して, Rabinovitch ら ${ }^{21)}$ は, (1)細胞突起より の出芽, (2)細胞内で形成された構造物の細胞外への突出, (3)細胞の変性, 崩壊, (4)細胞より分泌された subunit の細 胞外での集合, の 4 つの可能性を想定している. 第 2 の可 能性はミトコンドリアである. 石灰化巣形成におけるミト コンドリアの機能は, 特に生化学的また形態学的にも注目 されているが，この点に関しては Anderson ${ }^{3)} の$ 総説に詳 しい: ミトコンドリアに始まった石灰化の電顕像は, 松果 体部の肧芽腫 ${ }^{3)}$ ，下垂体腺腫 ${ }^{11)}$ 。単純へルペス脳炎 ${ }^{15)}$ など に扒いて報告されている。

微小X線分析では，カルシウムと燐に明らかなピーク が認められており，石灰化巣は水酸化燐灰石(hydroxyapatite)より形成されていることが示㖫された。この hydroxyapatite は, 生理的病的石灰化巣に抢けるもっと も一般的な物質である31).

我々は, 本腫瘍の石灰化巣増大の機序について次のよ5 に推論した。 まず初めに, 膜に包まれた類円形小体への針 状結晶の沈着が起こる. 次に, これらの多数の小石灰化巣 は互いに癒合し，またその一部はtonofibril に付着するが, いったん tonofibril に付着すると針状結晶はその付着部に 沿って拡がる，そして，ついには針状結晶が各 tonofibril 間の空隙をも埋め尽くすよ5に集積し，類円形小体内の石 灰化と混在して大きな 1 つの石灰化巣を形成すると考学ら れた。

\section{V 結 語}

頭蓋咽頭腫 8 例につき, 石灰化巣を中心に電顕により観 察を行った. 本腫瘍の大部分の石灰化は, 変性した角質細 胞に出現した多数の類円形小体内に針状結晶構造物が沈着 することにより始まる．この小石灰化巣は隣接する多数の tonofibril にも波及し，1 つの大きな石灰化巣を形成するも のと推定された。

\section{文献}

1) Anderson HC: Vesicles associated with calcification in the matrix of epiphyseal cartilage. J Cell Biol 41: 59-72, 1969

2) Anderson HC: Matrix vesicle calcification. Fed Proc 35: 105108, 1976

3) Anderson HC: Calcification processes. Pathol Annu 15: 45-75, 1980

4) Bernard GW: Ultrastructural observations of initial calcification in dentine and enamel. $J$ Ultrastruct Res 41: 1-17, 1972

5) Bernard GW, Pease DC: An electron microscopic study of ini- 
tial intramembranous osteogenesis. Amer $J$ Anat 125: 27!-290, 1969

6) Bonucci E: Fine structure and histochemistry of "calcifying globules" in epiphyseal cartilage. Z Zellforsch 103: 192-217, 1970

7) Brody I: The ultrastructure of the tonofibrils in the keratinization process of normal human epidermis. $J$ Ultrastruct Res 4: 264297,1960

8) Critchley $M$, Ironside RN: The pituitary adamantinomata. Brain 49: 437-481, 1926

9) Eisenman DR, Glick PK: Ultrastructure of initial crystal formation in dentin. $J$ Ultastruct Res 41: 18-28, 1972

10) Ghatak NR, Hirano A, Zimmerman HM: Ultrastructure of a craniopharyngioma. Cancer 27: 1465-1475, 1971

11) Ilse BG, Ryan N, Kovacs $K$, Ilse $D$ : Calcium deposition in human pituitary adenomas studied by histology, electron microscopy, electron diffraction and X-ray spectrometry. Exp Pathol 18: $377-381,1980$

12）石倉 彰 : 頭蓋咽頭腫の組織学的研究 一光学影做鏡的・電 子顕锺鏡的観察— 十全医会誌 83: 639-658, 1974

13) Kim KM: Calcification of matrix vesicles in human aortic valve and aortic media. Fed Proc 35: 156-162, 1976

14) Kubota T, Hirano A, Yamamoto $S$, Kajikawa K: The fine structure of psammoma bodies in meningocytic whorles. $J$ Neuropathol Exp Neurol 43: 37-44, 1984
15) Kubota T, Kusaka H, Hirano A, Llena J: Ultrastructural study of early stage of calcification in herpes simplex encephalitis. Acta Neuropathol (Berl) 68: 77-79, 1985

16) Kubota $T$, Sato K, Yamamoto $S$, Hirano A: Ultrastructural study of the formation of psammoma bodies in fibroblastic meningioma. J Neurosurg 60: 512-517, 1984

17) Landolt AM: Die Ultrastruktur des Kraniopharyngiomas. Schweiz Arch Neurol Neurochir Psychiatr 111: 313-329, 1972

18) Landolt AM: Ultrastructure of human sella tumors. Acta Neurochir (Wien) 22 [Suppl]: 104-119, 1975

19) Lee WR, Laurie J, Townsend AL: Fine structure of a radiation-induced osteogenic sarcoma. Cancer 36: 1414-1425, 1975

20）脳腫瘍全国統計委員会：脳腫瘍全国集計調査報告, vol 5 . 1984, p 11

21) Rabinovitch AL, Anderson HC: Biogenesis of matrix vesicle in cartilage growth plates. Fed Proc 35: 112-116, 1976

22) Russell DS, Rubinstein LJ: Pathology of Tumours of the Nervous System, ed 4. London, Edward Arnold, 1977, pp 32-35

23) Zülch K: Brain Tumors. New York, Springer, 1965, pp 228-233

〔別刷請求先： $\boldsymbol{\top} 910-11$ 福井県吉田郡松岡町下合月 23 , 福井医 科大学脳神経外科, 佐藤一史了 